\title{
PEMIKIRAN ISLAM TENTANG NAFS
}

\author{
Muh. Aidil Sudarmono \\ Mahasiswa Pascasarjana Doktoral UIN Alauddin Makassar \\ Email: sudarmono.aidil@yahoo.com
}

\section{Abstrak}

Pemahaman tentang jiwa pada manusia merupakan salah satu bagian dari kajian filsafat. Jiwa termasuk aspek trasendental yang secara johiriyah dan lahiriyah tidak dipisahkan dalam kajian tentang sisi manusia sebagai makhluk ciptaan Tuhan terutama merujuk kajian skriptual dalam konsepsi teologi Islam. Sehubungan dengan hal itu, beragam pendapat dan pandangan dari para pemikir Islam yang mengkonstruksikan makna jiwa sebagai Nafs yang mempunyai arti sebagai roh manusia, nyawa, seluruh kehidupan batin, sesuatu yang utama menjadi semangat, maksud sebenarnya, arti yang tersirat, dan buah hati. Lebih lanjut lagi, telaah konsepsi teologi Islam tentang jiwa dalam kaitannya dengan filsafat Islam akan bersandar pada dari akarnya yaitu al-nafs. Al-Nafs juga diartikan darah, karena seseorang apabila kehilangan darah maka ia kehilangan jiwanya. Meskipun dalam pemaknaan umum dipahami sesungguhnya jiwa dalam pandangan pemikir Islam terdapat kecnderungan memposisikan Jiwa sabagai Nafs juga berarti roh, hal ini dilihat dari beberapa ayat menyebutkan kata al-nafs dengan arti ruh yang berkaitan langsung dngan jasad manusia sebagai komponen fisik manusia. Pada aspek ini kata al-ruh dengan alnafs memiliki kedekatan makna, al-nafs berarti bernafas dan al-ruh yang jika dijamakkan, al-arwah adalah penentu hidup atau matinya manusia.

Kata Kunci: Pemikiran, Islam, Nafs

\section{Pendahuluan}

7 onsepsi tentang nafs, sebagaimana disampaiakn Abdul Munir dalam jurnalnya "konsep nafas dalam al-Qur'an" cenderung merujuk penjabaran al-Qur'an surat alDzuriyat ayat 21 Allah berfirman: "Dan tentang anfus kalian, apakah kalian tidak memperhatikan ("untuk menganalisisnya"). Menurut analisanya seruan Allah ini mengisyaratkan bahwa betapa 
pentingnya menganalisis diri pribadi (anfus) manusia. Di dalam alQur'an telah cukup banyak diterangkan tentang konsep manusia. Salah satu yang diterangkan dalam al-Qur'an adalah tentang rahasia-rahasia yang ada dalam diri manusia (anfus), sebagaimana firman Allah dalam surat Fushilat ayat 53, yang artinya: "Kami perlihatkan kepada mereka tanda-tanda kekuasaan Kami pada seluruh ufuk dan di dalam "anfus"mu sendiri, sehingga jelas bahwasannya alQur'an itu benar". Di dalam ayat tersebut terdapat kata anfus jama' dari kata nafs yang banyak disebut dalam al-Qur'an. Konsep tentang nafs dalam al-Qur'an banyak variasi maknanya. Hal itu disebabkan karena berasal dari bervariasinya makna katakata nafs itu sendiri dalam sumbernya, yaitu berbagai ayat dalam al-Qur'an. Quraish Shihab berpendapat, bahwa kata nafs dalam alQur'an mempunyai aneka makna, sekali diartikan sebagai totalitas manusia (QS:5;32), tetapi di tempat lain nafs menunjuk kepada apa yang terdapat dalam diri manusia yang menghasilkan tingkah laku (QS:13;11). Namun, secara umum dapat dikatakan bahwa nafs dalam konteks pembicaraan manusia, menunjuk kepada sisi dalam manusia yang berpotensi baik dan buruk. ${ }^{1}$

Dalam tradisi keilmuan Islam kajian jiwa justru mendapat perhatian penting. Hampir semua ulama, kaum sufi dan filosof muslim ikut berbicara tentangnya dan menganggapnya sebagai bagian yang lebih dahulu diketahui oleh seorang manusia. Karena dimensi jiwa dalam Islam lebih tinggi dari sekedar dimensi fisik karena jiwa merupakan bagian metafisika. Ia sebagai penggerak dari seluruh aktifitas fisik manusia. Meskipun saling membutuhkan antara jiwa dan jasad tanpa harus dipisahkan, namun peran jiwa akan lebih banyak mempengaruhi jasad. ${ }^{2}$ Berdasarkan hal inilah, maka perlu menguraikan kembali gambaran pemikiran para ulama, kaum sufi dan filosof muslim terkait suatu konsep tentang hakekat

${ }^{1}$ Abdul Munir, “Konsep nafs dalam al-Qur'an" (Jurnal 338 Ilmu Dakwah Vol. 16 No. 1, 2008), 1

"Syah Reza" Jiwa Dan Konsep Nafs dalam Islam" (http://inpasonline.com/ konsep-jiwa-menurut-islam) di akses Mei 2017. 
manusia yang tertera dalam ayat-ayat al-Qur'an yang berbunyi nafs. Pembahasan tentang nafs sangat menarik untuk dikaji, karena di dalam al-Qur'an cukup banyak menyebutnya. Hal ini menandakan bahwa pribadi manusia atau nafs itu sangat penting untuk dibahas dan dianalisis.

\section{Konsepsi Dasar Penelaahan Definisi Tentang Nafs}

Istilah nafs yang dimaksud disini adalah istilah bahasa Arab yang dipakai dalam al-Qur'an.Secara bahasa dalam kamus alMunjid, nafs (jamaknya nufus dan anfus) berarti roh (ruh) dan ain (diri sendiri). ${ }^{3}$ Sedangkan dalam kamus al-Munawir disebutkan bahwa kata nafs (jamaknya anfus dan nufus) itu berarti roh dan jiwa, juga berarti al-Jasad (badan, tubuh), as-Syakhs (orang), asSyahks al-Insan (diri orang), al-dzat atau al-Ain (diri sendiri). ${ }^{4}$ Sedangkan menurut Dawan Raharji dalam ensiklopedia al-Qur'an disebutkan bahwa dalam al-Qur'an nafs yang jamaknya anfus dan nufus diartikan jiwa (soul), pribadi (person), diri (self atau selves), hidup (life), hati (heart), atau pikiran (mind). ${ }^{5}$ Nafs atau jiwa mempunyai arti sebagai roh manusia, nyawa, seluruh kehidupan batin, sesuatu yang utama menjadi semangat, maksud sebenarnya, arti yang tersirat, dan buah hati. ${ }^{6}$

Telaah pemikiran Islam tentang jiwa dalam kaitannya dengan filsafat Islam akan ditilik dari akarnya yaitu al-nafs. Al-nafs dari huruf Nun, Fa, dan Sin menunjukkan arti keluarnya angin lembut bagaimanapun adanya. Al-Nafs juga diartikan darah, karena seseorang apabila kehilangan darah maka ia kehilangan jiwanya. ${ }^{7}$

\footnotetext{
${ }^{3}$ Lewis Makluf, al-Munjid fi al-Lughah Wa A'lam, (Beirut: Daar al-Masyriq, 1986), 826.

${ }^{4}$ Ahmad Warson Munawir, al-Munawir Kamus Arab Indonesia, (Yogyakarta: Pustaka Progressif, 1984), 1545.

${ }^{5}$ Darwan Raharjo, Ensiklopedia al-Qur'an: Tafsir Sosial Berdasarkan Konsep-Konsep Kunci, (Jakarta: Paramadina, 1996), 250.

${ }^{6}$ Tim Reality, Kamus Terbaru Bahasa Indonesia, (Surabaya: Reality Publisher, 2008), 215.

${ }^{7} \mathrm{Abu}$ al-Husain, Mu'jam Maqayis al-Lughah......,460.
} 
Nafs juga berarti roh $^{8}$, dan bila dilihat dari beberapa ayat menyebutkan kata al-nafs dengan arti ruh yang berkaitan langsung dngan jasad manusia sebagai komponen fisik manusia.

Pada aspek ini kata al-ruh dengan al-nafs memiliki kedekatan makna, al-nafs berarti bernafas dan al-ruh yang jika dijamakkan, al-arwah adalah penentu hidup atau matinya manusia. Bahasa keseharian jika ia tidak bernafas lagi maka ruhnya sudah tiada. Sebab itu pertanyaan apakah ruh dan jiwa sama atau berbeda?, maka penulis lebih cenderung memilih pendapat yang mengatakan bahwa perbedaan ruh dan jiwa adalah perbedaan sifat, bukan zat. ${ }^{9}$ Kata nafs di dalam al-Qur'an mempunyai arti yang beragam. Untuk melihat lebih jauh maka mari kita simak bersama yang terdapat dalam ayat-ayat al-Qur'an yang menjelaskan tentang jiwa dan ruh.

1. Bermakna Insan (manusia)

QS al-Maidah/5:32

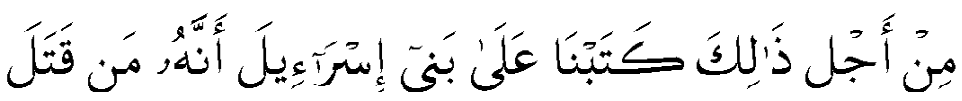

Terjemahnya:

"Barangsiapa yang membunuh seorang manusia, bukan Karena orang itu (membunuh) orang lain atau bukan Karena membuat kerusakan dimuka bumi, Maka seakan-akan dia Telah membunuh manusia seluruhnya"

QS al-Baqarah/2:48

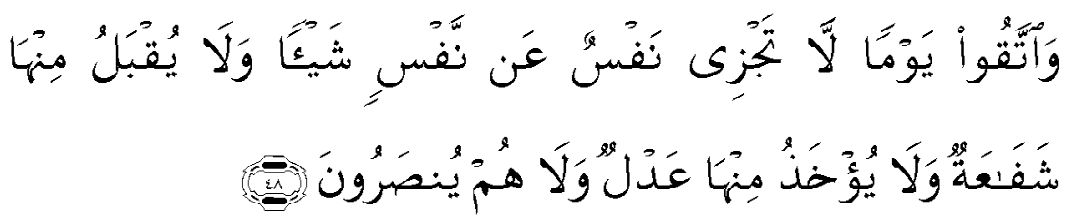

Terjemahnya:

"Dan jagalah dirimu dari (azab) hari (kiamat, yang pada hari itu) seseorang tidak dapat membela orang lain, walau sedikitpun;

${ }^{8}$ Asyiraf, al-Mu'jam al-Islami, (Kairo: Dar al-Syuruj, 2002), 679.

'Ibnu al-Qayyim, al-Ruh, (Jeddah: al-Haramin), 213. 
dan (begitu pula) tidak diterima syafa'at dan tebusan dari padanya, dan tidaklah mereka akan ditolong".

2. Bermakna zat Ilahiyah

QS Taahaa/20:41

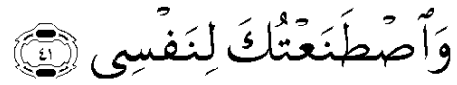

Terjemahnya: "Dan Aku Telah memilihmu untuk diri-Ku" QS al-An'am/6:12

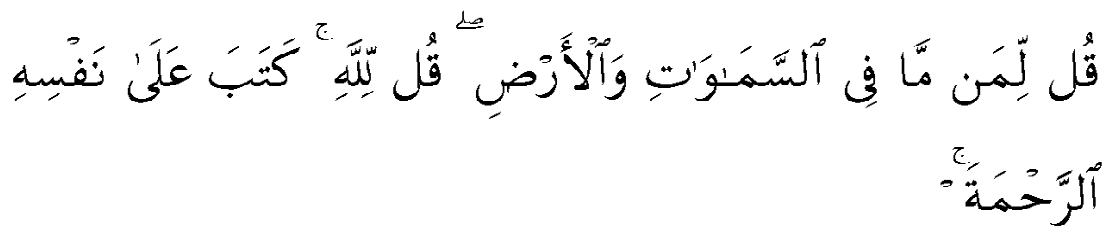

Terjemahnya:

"Katakanlah: "Kepunyaan siapakah apa yang ada di langit dan dibumi." Katakanlah: Kepunyaan Allah." dia Telah menetapkan atas Diri-Nya kasih sayang"

3. Bermakna isyarat terhadap apa yang tersirat di dalam jiwa manusia.

QS al-Ra'd/13:11

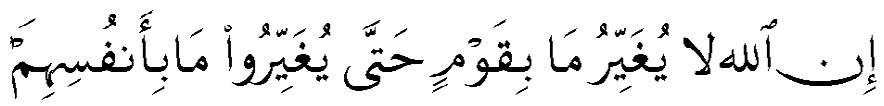

Terjemahnya: “Sesungguhnya Allah tidak merobah keadaan sesuatu kaum sehingga mereka merobah keadaan yang ada pada diri mereka sendiri".

QS Qaaf/50:16

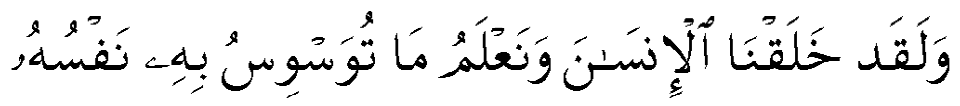

Terjemahnya: "Dan Sesungguhnya kami Telah menciptakan manusia dan mengetahui apa yang dibisikkan oleh hatinya" 
4. Bermakna satu asal keturunan manusia.

QS al-Nisa/4:1

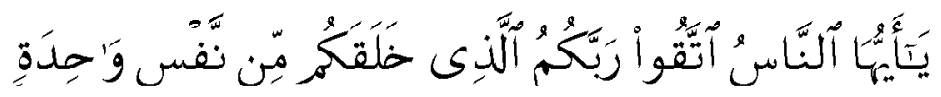

Terjemahnya: "Hai sekalian manusia, bertakwalah kepada Tuhan-mu yang Telah menciptakan kamu dari seorang diri"

5. Dalam hubungannya dengan makna substansi manusia dijabarkan dengan bentuk penyebutan nafsu-nafsu seperti nafsu amarah, nafsu lawwamah, dan nafsu mutmainnah.

QS Yusuf/12:53

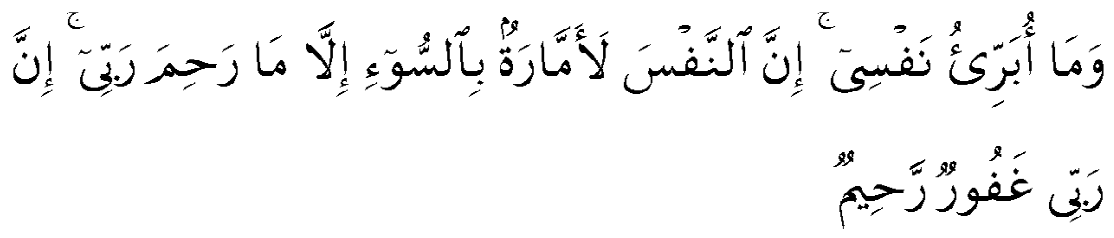

Terjemahnya:

“Dan Aku tidak membebaskan diriku (dari kesalahan), Karena Sesungguhnya nafsu itu selalu menyuruh kepada kejahatan, kecuali nafsu yang diberi rahmat oleh Tuhanku. Sesungguhnya Tuhanku Maha Pengampun lagi Maha penyanyang"

Dalam beberapa ayat ketika Tuhan menyebut kata al-Nafs yang dimaksudkan di dalamnya adalah al-ruh. (Misalnya dalam QS alFajr/89:27). Sebab itu maka dapat disimpulkan bahwa hakekar alNafs (jiwa) berasal dari al-ruh. Secara subtantif, Ruh adalah inti dan jiwa. Hal tersebut didasari dengan beberapa alasan. Pertama, Kata al-ruh didalam al-Qur'an selalu disebutkan dengan bentuk mufrad (tunggal), al-ruh tidak ada yang berbentuk jamak (al-arwah). Berbeda dengan kata al-Nafs disebutkan dalam bentuk tunggal maupun jamak. Kedua, Tidak ada kata al-ruh di dalam al-Qur'an yang secara eksplisit menunjuk pada arti ruh itu sendiri ataupun jiwa. Ketika Allah swt menyebut al-ruh yang dimaksud justru malaikat Jibril, kekuatan dirinya, atau al-Qur'an. Ini menunjukkan bahwa kata al-ruh digunakan kepada sesuatu yang lebih utama dari 
sekedar dipahami secara sederhana sebagai hembusan nafas atau substansi yang mewujudkan proses hidup tubuh manusia. Al-ruh (dalam makna ruh Tuhan, al-Qur'an atau malaikat Jibril) adalah hakekat yang menjadi sumber kehidupan manusia yang sempurna, asal segala kehidupan, yang memancarkan sinaran petunjuk kepada jiwa yang berkelana dalam kehidupan fisik manusia.

Dengan demikian Semua kata al-ruh merupakan ungkapan trasenden Tuhan, bahkan beberapa ayat. Ketika Allah swt menyebutkan kata al-ruh ia mengaitkannya dengan dirinya (ruhy), ini menunjukkan bahwa ruh memiliki unsure ketuhanan di dalamnya. Berbeda dengan kata al-nafs Allah swt menyebutkannya dengan sangat plural, hingga mengklasifikasikan berdasarkan kualitasnya kehidupan baik maupun buruk.Sebab itu jiwa memiliki unsur keTuhanan sekaligus memiliki unsur Syaitaniyah. Dua ranah kehidupan dalam diri manusia yang selalu bertarung sepanjang hidupnya. Siapa pemenang dialah yang akan menentukan pilihan dan mengendalikan tindakan.

\section{Pandangan Pemikir Islam Tentang Hakikat Nafs (Jiwa)}

\section{Menurut Al-Kindi}

Nama lengkapnya adalah Abu Yusuf Ya'qub Ibn Ishaq Ibn alsabab Ibn Imra Ibn Muhammad Ibn al-Asy'as Ibn Qais al-Kindi. Dinisbatkan ke Kindah nama sebuah kabilah terkemuka pra-Islam yang merupakan cabang dari Bani Kahlas yang menetap di Yaman. ${ }^{10}$ Ia dilahirkan di Kufah sekitar tahun $185 \mathrm{H}$ (801 M). ${ }^{11}$ Ada yang mengatakan lahir pada tahun $180 \mathrm{H}$ (796 M).Tentang kapan wafatnya, tidak ada suatu keterangan yang pasti. Agaknya menentukan tahun wafatnya sama sulitnya dengan menentukan tahun kelahirannya. Mustafa Abd al-Raziq cenderung mengatakan

${ }^{10}$ Muhammad Syafiq Garba, al-Arabiyah al-Muyassarah, (Kairo: Da>al Qalam \& Frankin Foundation: 1962), 63

${ }^{11} \mathrm{Al}$-Ahwal, al-Faisafah al-Islamiyah......, 63. 
tahun wafatnya adalah $252 \mathrm{H}$, sedangkan Massignon mengatakan $260 \mathrm{H}$. sementara itu, Yaqub mengatakan bahwa al-Kindi wafat sesudah berusia 80 tahun atau lebih sedikit. ${ }^{12}$

Al-Kindi berpendapat bahwa al-nafs adalah substansi yang tunggal, tidak tersusun, tidak panjang, dalam, dan lebar berciri Illahi lagi rohani, mempunyai arti sempurna dan mulia Al-nafs merupakan jalur rohani, maka hubungannya dengan tubuh bersifat aksidental. Kendatipun al-nafs bersatu dengan tubuh yang dengannya ia dapat melakukan kegiatannya. Namun al-nafs tetap terpisah dan berbeda dengan tubuh, sehingga ia kekal setelah tubuh mengalami kematian. ${ }^{13}$ Lebih lanjut ia berpandangan bahwa Jiwa mempunyai arti penting, sempurna, dan mulia. Substansi (jauhar)-nya berasal dari substansi Allah. Hubungannya dengan Allah sama dengan hubungan cahaya dan matahari. ${ }^{14}$ Jiwa mempunyai wujud tersendiri, terpisah dan berbeda dengan jasad.Jiwa bersifat rohani dan Ilahi sementara jasad atau jism mempunyai hawa nafsu dan marah. Argumen tentang bedanya jiwa dan jasad, Menurut al-Kindi adalah jiwa menentang keinginan hawa nafsu. Apabila nafsu marah mendorong manusia untuk melakukan kejahatan, maka jiwa menentangnya. Hal ini dapat dijadikan indikasi bahwa jiwa sebagai yang melarang tentu tidak sama dengan hawa nafsu yang dilarang.

\section{Menurut Al-Frabi}

Nama lengkapnya adalah Abu Nas Muhammad Ibn Muhammad Ibn Tarkhan Ibn Auzalagh, yang biasa disingkat saja dengan al-Farab.Ia dilahirkan di Wasij, Distrik Farab, Turkistan pada tahun $257 \mathrm{H} / 870$ M. ${ }^{15}$ Al-Farabi memberi perhatian besar pada

${ }^{12}$ Musa al-Musawi, Min al-Kindi Ibn Rusyd, (Beirut: Maktabah al-Fikr aljami'i:1977), 54-54

${ }^{13}$ M.M. Syarif, ed., History of Muslim Philosopy. Vol I, (Wisbaden: OttoHorossowitz. 1963), 432.

${ }^{14}$ Kamal al Yaaji, al-Nusba, al Nus.al-Falsafiyyah al-Muyassarah al-Musyassarah, ((Beirut: Daa al-Illm Ii al-Malay,1963), 74.

${ }^{15}$ Muhammad Ali Abu Rayyah, al-Faisafat al-islamyyah, (Alexandria: Maktabat al-Iskandariyah), 367. 
eksistansi jiwa dalam kaitannya dengan kekuatan berpikir. ${ }^{16}$ Menurutnya, jiwa yang ada dalam tubuh manusia beserta materi dasarnya memancar dari akal kesepuluh. Jiwa adalah jauhar rohani sebagai form bagi jasad. Kesatuan keduanya merupakan kesatuan secara accident.Artinya masing-masing keduanya mempunyai substansi yang berbeda dan binasanya jasad tidak membawa pada binasanya jiwa. Jiwa manusia disebut dengan al-nafs al-naqah, berasal dari alam Ilahi, sedangkan jasad berasal dari alam makhluk, berbentuk, berupa, berkadar, dan bergerak. ${ }^{17}$

Jiwa diciptakan tatkala jasad siap menerimanya jiwa. Tentang bahagia dan sengsaranya jiwa al-Farabi mengaitkan dengan filsafat negara utamanya (al-madinah al-fadillah).Bagi jiwa yang hidup pada negara utama, yakin jiwa yang kenal dengan Allah dan melaksanakan perintahNya. Jiwa ini menurut al-Farabi, akan kembali kealam nufus (alam kejiwaan) dan abadi dalam kebahagiaan. Jiwa yang hidup pada negara fasiqah, yakni jiwa yang kenal dengan Allah, tetapi tidak melaksanakan perintahnya-Nya.Ia kembali kea lam nafus dan abadi dalam kesengsaraan. Sementara jiwa yang hidup pada negara jabilah, yakni jiwa yang tidak kenal sama sekali dengan Allah dan tidak pula pernah melakukan perintah-Nya, ia lenyap bagaikan jiwa hewan ${ }^{18}$.

\section{Menurut Ibn Sina}

Nama lengkapnya adalah Abu Ali al-Husain ibn' Abd Allah ibn Hasan ibn 'Ali ibn Sina di Barat popular dengan Avicenna. Ia dilahirkan di Afsyana dekat Bukhara pada tahun $980 \mathrm{M}$ dan meninggal pada tahun $1037 \mathrm{M}$ dalam usia 58 tahun di Hamadza. ${ }^{19}$

${ }^{16}$ T. J. De Boer. The History of Philoshophy In Islam, (New York: Dover Publication ind. 1967), 107.

${ }^{17}$ Ahmad Daudy, Allah dan Manusia dalam Konsepsi Syekh Nuruddin ar_Raniry, (Jakarta: Rajawali, 1983), 136.

${ }^{18} \mathrm{Al}-\mathrm{Farabi}, \mathrm{Ara}$, Ahl al-Madinat al-Fadilah (Kairo: Maktabah Matabi'ah Muhammad Ali. t.th), 99-100.

${ }^{19}$ Muhammad Alif al-Iraqi.Al-Falsafat al-Islamiyah, (Kairo: Da al-Ma'arif, 1978), 43. 
Keistimewaan pemikiran Ibn Sina terletak pada filsafat jiwa. Menurut Ibn Sina, jiwa manusia sebagai jiwa-jiwa lain dan segala apa yang terdapat di bawah rembulan, memancar dari Akal Sepuluh. Secara garis besarnya pembahasan Ibn Sina tentang jiwa terbagi pada dua bagian:

\section{a. Fisika membicarakan tentang jiwa tumbuh-tumbuhan, hewan, dan manusia.}

1) Jiwa tumbuh-tumbuhan mempunyai tiga daya: makan, tumbuh, dan berkembang biak

2) Jiwa binatang mempunyai dua daya: gerak (mutaharrikah), dan menangkap (mudrikah).

3) Jiwa manusia disebut juga al-nafs al-naqah, mempunyai dua daya: praktis (amaliah) dan teoreti (alimah). Daya praktis hubungannya dengan jasad, sedangkan daya teoretis hubungannya dengan hal-hal yang abstrak ${ }^{20}$

\section{b. Metafisika, membicarakan tentang:}

Pertama, wujud jiwa. Dalam membuktikan adanya jiwa, Ibn Sina menggunakan empat dalil: a) Dalil alam kejiwaan; b) Konsep "aku"dan kesatuan fenomena psikologis; c) Dalil kontinutas (istimrar); dan d) Dalil manusia terbang. ${ }^{21}$ Kedua, Hakikat jiwa.Definisi jiwa yang dikemukakan Aristoteles ternyata tidak memuaskan Ibn Sina.Pasalnya definisi tersebut belum memberikan gambaran tentang hakikat jiwa yang membedakannya dari jasad.Untuk membedakan hakikat jiwa dari jasad, Ibn Sina mendefinisikan jiwa dengan jauhar rohani.Definisi ini mengisyaratkan bahwa jiwa merupakan substansi rohani, tidak tersusun dari materi-materi sebagaimana jasad.Kesatuan antara keduanya bersifat accident, hancurnya jasad tidak membawa pada hancurnya jiwa (roh). Pendapat inipun lebih dekat pada pendapat Plato. Ketiga, Hubungan jiwa 
dengan jasad Ibn Sina menerima pendapat Aristoteles tentang eratnya hubungan antara jiwa dan jasad. Namun hubungan yang bersifat esensial ia tolak karena membawa pada hancurnya jiwa dengan kehancuran jasad. Hal ini ia lebih cenderung sependapat dengan Plato bahwa hubungan keduanya bersifat accident. Binasanya jasad tidak membawa pada binasanya jiwa dan jasad.Keduanya saling mempengaruhi. Jasad adalah tempat bagi jiwa, adanya jasad merupakan syarat terciptanya jiwa dengan kata lain jiwa tidak akan diciptakan tanpa adanya jasad yang akan ditempatinya ${ }^{22}$. Jika tidak demikian tentu aka nada jiwa tanpa jasad, atau ada satu jasad ditempati beberapa jiwa, dan kenyataan tidak demikian. Keempat, Kekekalan Jiwa. Seperti dikatakan bahwa manusia diciptakan setiap kali jasad yang akan ditempatinya telah didakan. Pendapat ini sekaligus menolak konsep Plato yang berkesimpulan bahwa jiwa sudah ada di dalam idea sebelum jasad yang akan ditempati ada.Ibnu Sina kelihatannya lebih cenderung berkesimpulan sesuai dengan apa yang disinyalkan al-Qur'an. Menurutnya jiwa manusia berbeda dengan tumbuhan dan hewan yang hancur dengan hancurnya jasad. Jiwa manusia akan kekal dalam bentuk individual yang akan menerima pembalasan (bahagia dan celaka) di akhirat. Akan tetapi kekalnya ini dikekalkan Allah swt.jadi jiwa adalah baharu karena diciptakan (punya awal) dan kekal (tidak punya akhir). ${ }^{23}$

\section{Menurut Ibnu Miskawaih}

Nama lengkapnya adalah Abu Ali Ahamad Ibn Muhammad Ibn Ya'kub Ibnu Misakawaih. Dilahirkan di kota Rayy, Iran pada tahun $330 \mathrm{H} / 941 \mathrm{M}$ dan wafat pada tanggal 9 safar $421 \mathrm{H} / 16$ februari

\footnotetext{
${ }^{21}$ Ibrahim Madkur, Fizal-Falsafat al-Islamiyah, Manhaj wa Tatbiq (Kairo: DajalMa'arif, 1968), 145-147.

${ }^{22}$ Ibrahim Madkur, Fi al-Filsafat al Islamiyah, Manhaj wa Tatbiq, (Kairo: Daa alMa'arif, 1968), 145-147

${ }^{23}$ Ibrahim Madkur, Fi al-Filsafat al Islamiyah, Manhaj wa Tatbiq, 182-182.
} 
1030 M..$^{24}$ Jiwa menurut Ibnu Miskawaih adalah jauhar rohani yang tidak hancur dengan kematian jasad. Ia adalah kesatuan yang tidak terbagi-bagi. Ia akan hidup selalu. Ia tidak dapat diraba dengan pancan indera karena ia bukan jism. Jiwa dapat menangkap keberadaan zatnya dan ia mengetahui ketahuan dan keaktivitasannya. Argument yang diajukannya adalah jiwa dapat menangkap bentuk sesuatu yang berlawanan dalam waktu yang bersamaan, seperti warnah hitam putih sedangkan badan tidak dapat demikian. ${ }^{25}$ Tentang balasn di akhirat sebagaimana al-Farabi dan Ibnu maskawaih juga menyatakan bahwa jiwalah yang akan menerima balasan (kebahagiaan dan kesengsaraan) di akhirat. Karena menurutnya kelesatan jasmaniah bukanlah kelesatan yang sebenarnya. ${ }^{26}$

\section{Menurut Ikhwan al-Safa}

Ikhwan al-Safa adalah sekelompok pemikir muslim rahasia (filosofiko-religius) berasal dari sakte syi'ah ismailiyyah yang lahir di tengah-tengah komunitas sunni sekitar abad ke $4 \mathrm{H} / 10 \mathrm{M}$, di Basrah. Jiwa manusia menurut Ikhwan al-Safa bersumber dari jiwa universal. Perkembangan jiwa manusia banyak dipengaruhi materi yang mengitarinya. Agarjiwa tidak kecewa dalam perkembangannya maka jiwa dibantu oleh akal yang merupakan daya bagi jiwa untuk berkembang. Tubuh manusia jiwa memiliki tiga fakultas yaitu jiwa tumbuhan, jiwa hewan, dan jiwa manusia. Ketiga fakultas jiwa tersebut bersama dengan daya-dayanya bekerja sama dan menyatu dalam diri manusia. Disinilah letak kelebihan dari makhluk ciptaan Allah swt.yang lain. Sementara itu tentang kebangkitan di akhirat, Ikhwan al-Safa sama pendapatnya dengan filosof muslim lainnya yakni kebangkitan berbentuk rohani. Surga dan neraka dipahami dalam makna hakikat. Surga adalah kesenangan dan neraka adalah penderitaan. ${ }^{27}$

${ }^{24}$ Muhammad Yusuf Musa, Filsafat Akhlak Fi al-Islami, (Kiro: Dar al-Ma'arif, 1945), 71.

${ }^{25}$ T. J. De Boer. The History of Philoshophy In Islam.......,186.

${ }^{26}$ Muhammad Yusuf Musa, Filsafat Akhlak Fi al-Islami........,72.

${ }^{27}$ Sirajuddin, Filsafat Islam: Filosof dan Filsafatnya, (Jakarta: Rajawali Pers, 2004), 152-153. 


\section{Menurut Ibnu Bajjah}

Adalah filosof muslim yang pertama dan utama dalam sejarah kefilsafatan di Andalus. Nama lengkapnya adalah Abu Bakar Muhammad Ibn Yahya Ibn al-Sa'igh yang lebih terkenal dengan nama Ibn Bajjah. Dia dilahirkan di Saragoza akhir abad ke $5 \mathrm{H} /$ abad ke $11 \mathrm{M}$. Menurut pendapat Ibn Bajjah setiap manusia mempunyai satu jiwa. Jiwa ini tidak mengalami perubahan sebagaimana jasmani.Jiwa adalah penggerak bagi manusia.Jiwa digerakkan dengan dua jenis alat yaitu alat-alat jasmaniah dan alat-alat rohaniah. Jiwa menurut Ibn Bajjah adalah jauhar rohani akan kekal setelah mati di akhirat, jiwalah yang akan menerima pembalasan, baik balasan kesenangan (surga) maupun balasan siksaan (neraka).

\section{Menurut Ibn Tufail}

Menurut Ibn Tufail jiwa manusia adalah makhluk Tuhan yang tertinggi martabatnya.Manusia terdiri dari dua unsure yakni jasad dan roh.Badan tersusun dari unsure-unsur sedangkan jiwa tidak tersusun.Jiwa bukanjism dan bukan pula suatu daya yang ada dalam jism.Setelah badan hancur atau mengalami kematian jiwa lepas dari badan dan selanjutnya jiwa yang pernah mengenal Allah swt.selama berada dalam jasad akan hidup dan kekal. ${ }^{28}$ Pendapat para filosof muslim di atas maka dapat dinyatakan beberapa hal berikut.

\section{Konsensus pemaknaan Nafs/Jiwa dalam Diri Manusia}

\section{Tentang esensi jiwa (mahiyat al-nafs)}

Beberapa filosof muslim seperti al-Farabi, Ibnu Sina, Ibnu Miskawaih, al-Kindi, Ibn Bajjah berpendapat hampir sama tentang makna jiwa. Mereka berpendapat bahwa jiwa adalah jauhar (substansi) rohani sebagai form bagi jasad. Hubungan kesatuan jiwa dengan badan merupakan kesatuan secara accident.Artinya keduanya tidak dapat dibagi-bagi tetapi keduanya berdiri sendiri

\footnotetext{
${ }^{28}$ Sirajuddin, Filsafat Islam: Filosof dan Filsafatnya......,194-195.
} 
dan mempunyai substansi yang berbeda sehingga binasanya jasad tidak membawa binasa pada jiwa. Pendapat mereka lebih dekat pada Plato yang mengatakan bahwa jiwa adalah substansi yang berdiri sendiri.

\section{Tentang kekekalan jiwa}

Semua filosof muslim yang mengatakan bahwa jiwa adalah substansi rohani sendiri. Juga meyakini bahwa jiwa memiliki kekekalan dan tidak hancur.Ibnu Thufail mengatakan bahwa setelah badan hancur atau mengalami kematian jiwa lepas dari badan.Selanjutnya jiwa yang pernah mengenal Allah swt. Selama berada dalam jasad akan hidup dan kekal. ${ }^{29}$ Pembuktian kekalnya jiwa, Ibnu sina mengemukakan tiga dalil, yaitu:

a. Dalail infisal (bukti perpisahan). Perpaduan jiwa dan jasad bersifat aksiden keduanya memiliki substansi tersendiri dan jika jasad mati atau hancur jiwa tetap dan kekal sementara jasad bergantung kepada jiwa untuk bisa hidup.

b. Dalil al-Basatah (bukti keluasan). Jiwa adalah jauhar (substansi) rohani yang luas. Dengan keluasannya ia selalu hidup dan tidak mati. Karenanya jiwa dinamakan juga jauhar basit (hidup selalu).

c. Dalil al-Musyababah (bukti persamaan). Dail ini bersifat metafisika.Jiwa manusia sesuai filsafat emanasi bersumber dari akal fa'al (akal kesepuluh) segala pemberi segala bentuk. Karena akal kesepuluh adalah merupakan esensi yang berfikir, azali, dan kekal maka jiwa sebagai ma'lul (akibat) nya juga akan kekal sebagaimana illat (hidup selalu). ${ }^{30}$

\section{Tentang daya jiwa (quwwat al-nafs)}

Menurut Ibnu Sina jiwa dibagi menjadi tiga tingkatan yaitu jiwa vegetative, jiwa binatang, dan jiwa kemanusiaan. Yang dimaksud

\footnotetext{
${ }^{29}$ Sirajuddin, Filsafat Islam: Filosof dan Filsafatnya......., 217.

${ }^{30}$ Sirajuddin, Filsafat Islam: Filosof dan Filsafatnya......, 111.
} 
dengan jiwa vegetative yaitu seperti makan, tumbuh dan berkembang biak. Sedangkan jiwa binatang yang mempunyai dua daya yaitu daya tangkap dan daya penggerak.Jiwa manusia mempunyai dua daya yaitu praktis dan teoritis.Menurut Ikhwan alSafa daya jiwa vegetative dimiliki semua makhluk hidup baik hewan, manusia, dan tumbuh-tumbuhan. Karena semua makhluk memiliki keinginan untuk makan tumbuh dan berkembang biak. Sedangkan daya jiwa binatang hanya dimiliki manusia dan hewan. Adapun daya jiwa yang ketiga hanya dimiliki oleh manusia yang menyebabkan mereka bisa berfikir dan berbicara. Al-Farabi mengklasifikasikan daya jiwa lebih simple yaitu daya gerak, untuk jenis jiwa pertama, daya yang mendorong untuk berimajinasi dan merasa, dan daya berfikir.

\section{Penutup}

Jiwa kadangkala diartikan sebagai sesuatu yang berbentuk fisik yang materil melekat pada diri manusia, tampak dan tidak tersembunyi, akan tetapi diwaktu lain ia mengandung arti sebagai sesuatu yang berbentuk non materil yang mengalir pada diri fisik manusia sebagai jauhar (substansi), substansi ruh ataupun substansi pikir. Hal ini ditegaskan oleh para Pemikir Islam tentang Jiwa seperti; Al-Kindi, Al-Farab, Ibnu Sina, Ibnu Miskawai, Ikhwan al-Safa, Ibnu Bajjah, dan Ibnu Tufail. Meskipun secara konsensus para filosof berpendapat hampir sama tentang maknajiwa. Mereka berpendapat bahwa jiwa adalah jauhar (substansi) rohani sebagai form bagi jasad. Hubungan kesatuan jiwa dengan badan merupakan kesatuan secara accident.Artinya keduanya tidak dapat dibagi-bagi tetapi keduanya berdiri sendiri dan mempunyai substansi yang berbeda sehingga binasanya jasad tidak membawa binasa pada jiwa.

Sejalan dengan hal itu, penulis juga sependapat dengan pandangan Abdul Munir dalam dalam jurnalnya "konsep nafas dalam al-Qur'an" yang menguraikan secara sederhana bahwa kata nafs dalam al-Qur'an itu menunjuk pada totalitas manusia, 
dilihatnya dalan dua hal antara lai; Pertama, Nafs dapat mengandung pengertian jiwa, tetapi juga sekaligus berarti diri, nafs dalam arti jiwa dipahami sebagai totalitas daya-daya ruhani berikut internalisasi dan aktualisasinya dalam kehidupan manusia. Kedua, Nafs juga berarti pribadi seseorang (person), nafs dapat juga berarti hati yang memberikan komando guna mengatur seluruh potensi manusia, dan nafs juga berarti "aku” manusia. Selain daripada itu, kata nafs juga berarti nafsu atau syahwat, namun nafs dalam pengertian nafsu berbeda dengan syahwat yang pejoratif, nafs bersifat netral bisa baik maupun buruk, tetapi pada dasarnya nafs berkecenderungan baik. Nafs juga diartikan ruh atau nyawa, tapi berbeda al-ruh, nafs mempunyai pengertian umum, bersifat material sekaligus immaterial. Dari konsep nafs inilah para filosof dan ahli tasawuf mengembangkan teori kepribadian manusia dalam perspektif Islam.

\section{Daftar Pustaka}

Abdul Munir, “Konsep nafs dalam al-Qur'an” (Jurnal 338 Ilmu Dakwah Vol. 16 No. 1, 2008.

Abu Rayyah, Muhammad Ali. al-Faisafat al-islamyyah. Alexandria: Maktabat al-Iskandariyah.

Al-Farabi. Ahl al-Madinat al-Fadilah. Kairo: Maktabah Matabi'ah Muhammad Ali. t.th.

Alif al-Iraqi, Muhammad. Al-Falsafat al-Islamiyah. Kairo: Da alMa'arif, 1978.

al-Qayyim, Ibnu. al-Ruh. Jeddah: al-Haramin.

Asyiraf. al-Mu'jam al-Islami. Kairo: Dar al-Syuruj, 2002.

Azis, Abd. Pokok-Pokok Kesehatan Jiwa/Mental. Jakarta: Bulan Bintang: 1974.

Daudy, Ahmad. Allah dan Manusia dalam Konsepsi Syekh Nuruddin ar_Raniry. Jakarta: Rajawali, 1983.

Ibrahim Madkur, Fi al-Filsafat al Islamiyah, Manhaj wa Tatbiq. Kairo: Daa al-Ma'arif, 1968. 
Kamal al Yaaji, al-Nusba. al Nus.al-Falsafiyyah al-Muyassarah alMusyassarah. Beirut: Daa al-Illm Ii al-Malay,1963.

Lewis, Makluf. al-Munjid fi al-Lughah Wa A'lam. Beirut: Daar alMasyriq, 1986.

M.M. Syarif, ed., History of Muslim Philosopy. Vol I. Wisbaden: OttoHorossowitz. 1963.

Munawir, Ahmad Warson. al-Munawir Kamus Arab

Indonesia.Yogyakarta: Pustaka Progressif, 1984.

Musa al-Musawi, Min al-Kindi Ibn Rusyd. Beirut: Maktabah al-Fikr al-jami'i:1977.

Nasution, Harun. Falsafat dan MIstisisme dalam Islam.

Raharjo, Darwan. Ensiklopedia al-Qur'an: Tafsir Sosial Berdasarkan Konsep-Konsep Kunci. Jakarta: Paramadina, 1996.

Sirajuddin. Filsafat Islam: Filosof dan Filsafatnya.Jakarta: Rajawali Pers, 2004.

Syafiq Garba, Muhammad. al-Arabiyah al-Muyassarah. Kairo: Daal Qalam \& Frankin Foundation: 1962.

Syah Reza" Jiwa Dan Konsep Nafs dalam Islam" (http:// inpasonline.com/konsep-jiwa-menurut-islam) di akses Mei 2017.

T. J. De Boer. The History of Philoshophy In Islam. New York: Dover Publication ind. 1967.

Tim Reality. Kamus Terbaru Bahasa Indonesia. Surabaya: Reality Publisher, 2008.

Yusuf Musa, Muhammad. Filsafat Akhlak Fi al-Islami. Kiro: Dar alMa'arif, 1945. 